\title{
Biocomposites Produced from Hardwood Particles by Equal Channel Angular Pressing Without Additives
}

\author{
Yu Bai ${ }^{1, *}$, Xiaoqing Zhang ${ }^{2}$ and Kenong Xia ${ }^{1, *} * \mathbb{C}$ \\ 1 Department of Mechanical Engineering, The University of Melbourne, Parkville, VIC 3010, Australia \\ 2 CSIRO Manufacturing, Private Bag 10, Clayton South MDC, VIC 3169, Australia; Xiaoqing.Zhang@csiro.au \\ * Correspondence: ybai1@student.unimelb.edu.au (Y.B.); k.xia@unimelb.edu.au (K.X.); \\ Tel.: +61-3-8344-6664 (K.X.)
}

Received: 28 February 2019; Accepted: 30 March 2019; Published: 3 April 2019

\begin{abstract}
Equal channel angular pressing (ECAP) has been shown to be a promising method for producing biocomposites from wood particles. However, severe plastic deformation during ECAP would cause considerable cracking when consolidation is carried out without a binder. In this study, the processing conditions were investigated for ECAP of hardwood particles into bulk biocomposites without any additives. Crack formation and wood cell deformation were examined in conjunction with thermal stability and crystallinity of the biocomposites. In comparison with hot pressing without severe shearing, a decrease in crystallinity and severe deformation of wood cells occurred during ECAP. Improved processability and homogeneous deformation would occur at high ECAP temperature (e.g., $210^{\circ} \mathrm{C}$ ) or low ECAP speed (e.g., $10 \mathrm{~mm} / \mathrm{min}$ ), leading to reduced crack formation in the ECAP-produced biocomposites. Despite its tendency to cause periodic cracking, effective plastic deformation in the regions between cracks was shown to improve interparticle binding. Ongoing research points to the potential achievement of crack-free hardwood (HW) consolidated without a binder, leading to significantly enhanced strength.
\end{abstract}

Keywords: biocomposites; hardwood particles; equal channel angular pressing (ECAP); severe plastic deformation

\section{Introduction}

Equal channel angular pressing (ECAP) is a well-known process of severe plastic deformation, during which the material is pressed through two channels of the same cross-section intersecting at an angle (usually 90 degrees), with severe shear happening at the intersection [1]. ECAP can be used to refine grain sizes of bulk polycrystalline metals and consequently improve their mechanical properties and superplastic formability [1]. In addition, it can be used to consolidate metal particles at lower temperatures than those used in conventional sintering, producing novel alloys and composites with enhanced properties [2]. ECAP has also been applied to amorphous and semi-crystalline polymers, altering molecular morphologies and orientations and leading to improved mechanical properties [3-5]. More recently, ECAP has been utilized to effectively consolidate cellulose-based particles into bulk biocomposites at relatively low temperatures, resulting in good mechanical properties [6-8], demonstrating its potential in producing biocomposites from raw agriculture waste, including cellulose and lignin-based materials.

However, since the rigid crystalline cellulose lacked the mobility to sustain large plastic deformation, adequate processability was hard to achieve in ECAP without additives and the consolidated biocomposites had low flexural strength $(<10 \mathrm{MPa})$ and elastic modulus ( $<1 \mathrm{GPa})$, with visible cracks forming along the shear direction at low processing temperatures $\left(130-150{ }^{\circ} \mathrm{C}\right)$ [7]. Although using additives such as polyethylenimine (PEI) was effective in improving the ECAP 
processability and flexural properties [9], it is important to understand the deformation and fracture mechanisms during ECAP of wood particles without additives, with a view to eliminating cracking and the need for binders. In this study, ECAP consolidation of wood particles without additives was carried out to examine the formation of cracks and deformation of wood cells under varied ECAP processing conditions, especially temperature and pressing speed. The effects on crystallinity and thermal stability of the biocomposites were also studied.

\section{Materials and Methods}

The maple hardwood (HW) particles were obtained from American Wood Fibers, with a particle size distribution of $>850 \mu \mathrm{m}(0-15 \mathrm{wt} \%), 425-850 \mu \mathrm{m}(25-80 \mathrm{wt} \%), 250-425 \mu \mathrm{m}(>20 \mathrm{wt} \%)$, and $<250 \mu \mathrm{m}(0-15 \mathrm{wt} \%)$. The ECAP set-up was the same as shown previously [10], with a $90^{\circ}$ angle between channels of $9 \times 9 \mathrm{~mm}$ in cross section. The HW particles were pressed at a constant back pressure of $\sim 70 \mathrm{MPa}$, producing samples of $40-50 \mathrm{~mm}$ in length. To investigate the effects of processing parameters, ECAP pressing speeds of 10,25 , and $50 \mathrm{~mm} / \mathrm{min}$, respectively, were employed at $200{ }^{\circ} \mathrm{C}$ (controlled to $\pm 2{ }^{\circ} \mathrm{C}$ ), or a fixed speed of $25 \mathrm{~mm} / \mathrm{min}$ was used with varied temperatures between 160 and $210^{\circ} \mathrm{C}$. Polytetrafluoroethylene coating on die surfaces was applied to reduce friction between the particles and the ECAP channel wall.

The samples produced are designated by using $\mathrm{S}$ for pressing speed and $\mathrm{T}$ for temperature. For example, ECAP-S25-T200 indicates a sample produced by ECAP at $25 \mathrm{~mm} / \mathrm{min}$ and $200{ }^{\circ} \mathrm{C}$. For comparison, the HW particles were also compacted and pressed at $200{ }^{\circ} \mathrm{C}$ and $25 \mathrm{~mm} / \mathrm{min}$ in the entrance channel of the ECAP die without going through the shearing zone, and held for $2 \mathrm{~min}$ so that the total heating time was about the same as that for ECAP-S25-T200; this was similar to processing by hot pressing, and the sample was designated as HP-T200.

The microstructures of the biocomposites were examined by optical microscopy $(\mathrm{OM})$ including Olympus BH2-UMA (compound) and Leica M205A (dissecting) and scanning electron microscopy (SEM) using FEI Quanta 200 ESEM FEG with an accelerating voltage of 5 or $10 \mathrm{kV}$. HW particles embedded in resin and the longitudinal section of consolidated samples were ground and polished using silicon carbide paper and diamond paste $(3 \mu \mathrm{m})$ for OM and further gold-coated for SEM.

For crystallinity and crystallite size measurements, wide-angle X-ray diffraction (XRD) on HW particles and sawdust of consolidated samples was conducted using a Bruker D8 Advance X-ray diffractometer with $\mathrm{Ni}$ filtered $\mathrm{Cu} \mathrm{K} \alpha$ radiation $\left(1.54 \AA\right.$ ) in the $2 \theta$ range of $5-85^{\circ}$. After subtracting a linear baseline from the XRD pattern, the relative cellulose crystallinity index (CI) was calculated by the peak height method [11]. The Multi-peak Fit Analysis in Igor Pro was used for deconvolution based on Gaussian profiles. The average dimensions corresponding to $2 \theta$ of $\sim 22^{\circ}$ (200) and $\sim 34.6^{\circ}$ (004), associated with crystallite width $\mathrm{D}_{200}$ and crystallite length $\mathrm{L}_{004}$, respectively, were estimated using the Scherrer equation [12], with the full width at half maximum of diffraction peak obtained from the previous deconvolution. The d-spacing between the (200) planes, $\mathrm{d}_{200}$, was calculated using Bragg's Law.

A Thermo Fisher Scientific Nicolet 6700 FT-IR Spectrometer (Thermo Scientific, Waltham, MA, USA) was used to characterize the molecular vibration of the functional groups in the as-received HW and sawdust of consolidated samples. The scan was carried out in the range of $600-4000 \mathrm{~cm}^{-1}$, with the spectrum showing the average of 64 scans at a resolution of $4 \mathrm{~cm}^{-1}$. After subtracting the baseline, the obtained spectra were vector normalized for comparison.

A Mettler Toledo thermogravimetric analyzer TGA/SDTA851e (Mettler Toledo, Columbus, OH, USA) was used to assess thermal stability. A sample of $\sim 10 \mathrm{mg}$ was heated from 25 to $600{ }^{\circ} \mathrm{C}$ at $10{ }^{\circ} \mathrm{C} / \mathrm{min}$ under $20 \mathrm{~mL} / \mathrm{min}$ nitrogen purge. The mass loss versus time and temperature was recorded, yielding the mass loss (TGA) and differential mass loss (DTG) curves. 


\section{Results}

The microstructure of HP-T200 is shown in Figure 1, with the pressing direction set at vertical. The HW particles were compacted with their longitudinal direction aligned normal to the pressing direction, and many cracks between particles (white arrowed) can be observed. In contrast, ECAP-S25-T200, as shown in Figure 2, displays periodic cracks across the width along the shear plane $\left(\sim 45^{\circ}\right.$ relative to the pressing direction) but no cracks between particles. These periodic cracks appeared to be thicker, with branches at a lower temperature of $190{ }^{\circ} \mathrm{C}$, compared to those at $210{ }^{\circ} \mathrm{C}$, as shown in Figure $3 a, b$, respectively. Shear bands, in which severe deformation had significantly distorted the wood particles, were formed at $\sim 45^{\circ}$ to the pressing direction at 200 and $210{ }^{\circ} \mathrm{C}$ (Figure $4 \mathrm{a}, \mathrm{b}$ ). On the other hand, a thinner shear band at the extension of a periodic crack was found at a higher pressing speed (Figure 4c). At $190{ }^{\circ} \mathrm{C}$ (Figure 4d), thin cracks were present without any formation of shear bands.

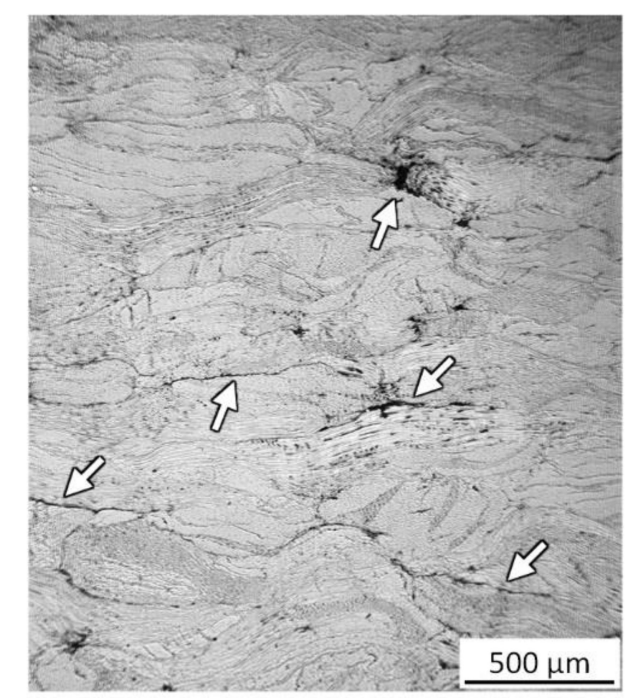

Figure 1. Optical microscopy (OM) microstructure of HP-T200 showing cracks (white arrows) between hardwood (HW) particles. The pressing direction is vertical.

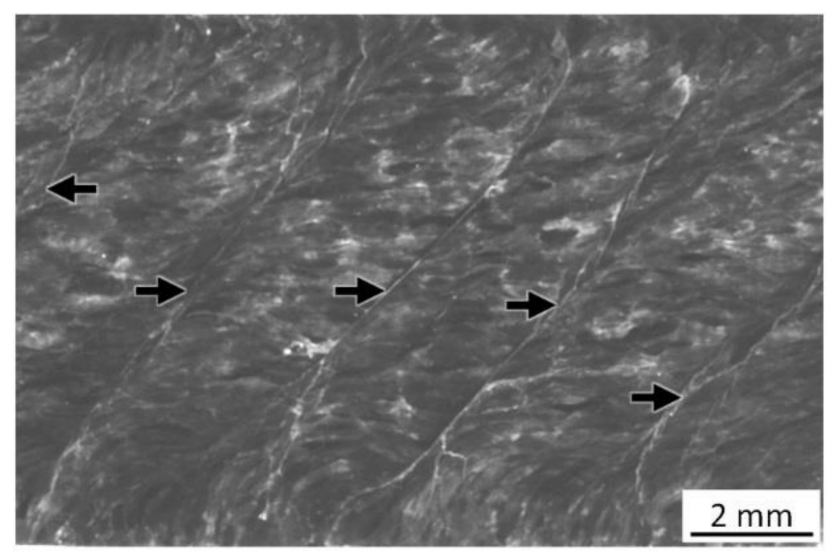

Figure 2. Image (dissecting OM) of ECAP-S25-T200, showing periodic cracks across the sample width (black arrows) but no cracks between particles, as well as particles away from the surfaces (i.e., in the middle section) aligned almost along the pressing direction which is horizontal to the right. 

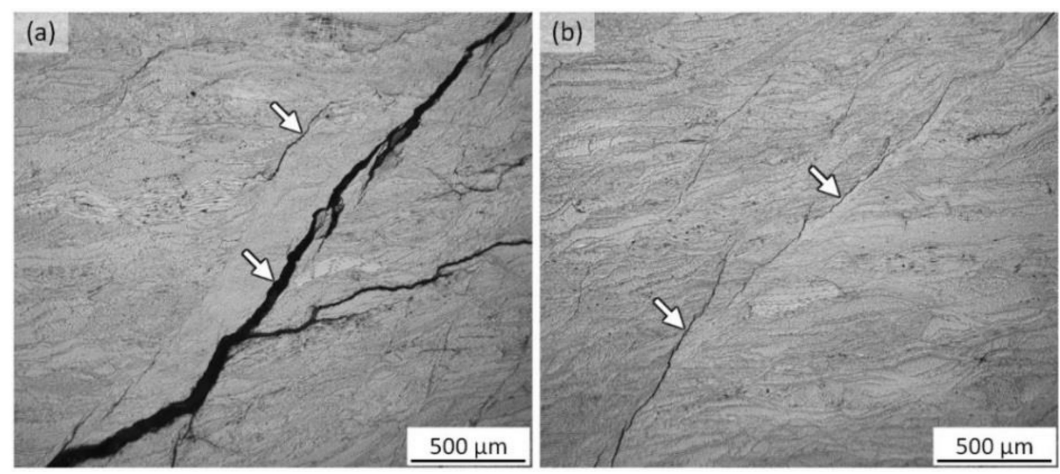

Figure 3. OM microstructures showing cracks (white arrows) in (a) ECAP-S25-T190 and (b) ECAP-S25-T210. The pressing direction is horizontal to the right.
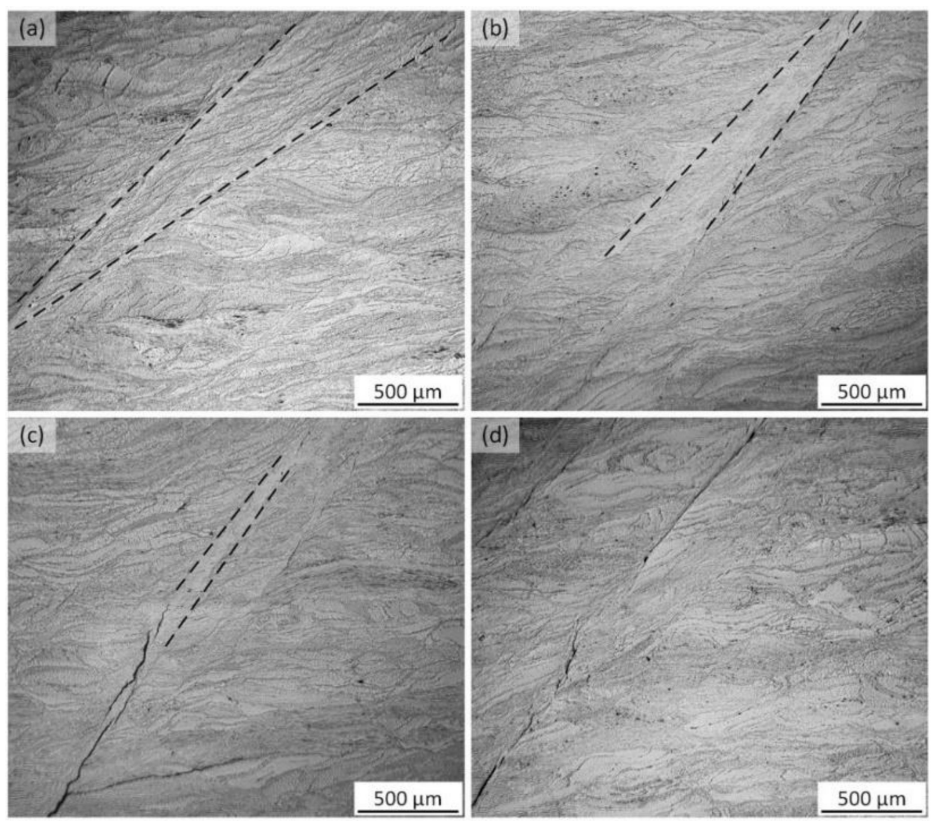

Figure 4. $\mathrm{OM}$ microstructures showing shear bands marked between the dashed lines in (a) ECAP-S10-T200, (b) ECAP-S25-T210, and (c) ECAP-S50-T200, while small crack with no shear bands are seen in (d) ECAP-S25-T190. The pressing direction is horizontal to the right.

The wood cells before and after ECAP can be revealed by SEM, as shown in Figure 5. The open lumina in the as-received HW (Figure 5a) were closed after the collapse of cell walls following hot pressing (Figure $5 b$ ) and ECAP (less deformed region away from periodic cracks in Figure $5 c$ or next to a periodic crack in Figure 5d). However, in the severely deformed region next to a periodic crack (Figure 5e) or within a shear band (Figure 5f), the cell walls were significantly distorted and could not be distinguished.

The XRD results of HW under various conditions are summarized in Table 1. After HP, the CI was reduced from 62 in HW to 50\%, and further to $35-40 \%$ after ECAP. ECAP also led to decreases in $\mathrm{D}_{200}$ and increases in $\mathrm{L}_{004}$. A larger $\mathrm{d}_{200}$ (suggesting more crystallite distortion) is generally correlated to a smaller $\mathrm{D}_{200}$, as also found in a previous study [13]. 

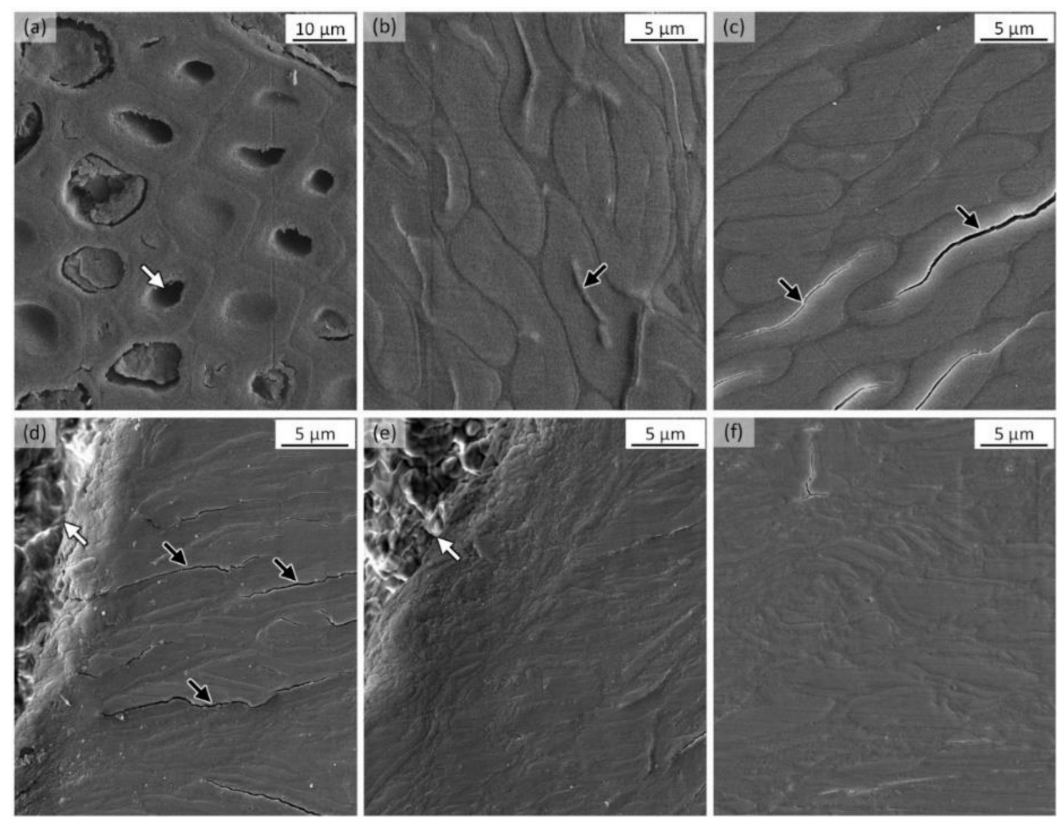

Figure 5. Scanning electron microscopy (SEM) microstructures of (a) un-deformed wood cells in the as-received HW, with the white arrow pointing to a lumen, deformed wood cells with collapsed lumina (black arrows) in (b) HP-T200, the (c) region away from periodic cracks and (d) next to a crack (white arrow) in ECAP-S25-T200, and highly distorted wood cells (e) close to a periodic crack (white arrow) in ECAP-S25-T200 and (f) in a shear band in ECAP-S10-T200, with hardly distinguishable cell wall structures. The pressing direction is horizontal to the right for HP-T200, ECAP-S25-T200, and ECAP-S10-T200.

Table 1. X-ray diffraction (XRD) results of HW under various conditions.

\begin{tabular}{ccccc}
\hline Material & $\begin{array}{c}\text { Crystallinity } \\
\text { Index (CI) }(\mathbf{\%})\end{array}$ & $\mathbf{D}_{\mathbf{2 0 0}}(\mathbf{n m})$ & $\mathbf{d}_{\mathbf{2 0 0}}(\mathbf{n m})$ & $\mathbf{L}_{\mathbf{0 0 4}}(\mathbf{n m})$ \\
\hline HW & 62 & 3.0 & 0.40 & 3.0 \\
HP-T200 & 50 & 2.9 & 0.40 & 3.7 \\
ECAP-S10-T200 & 35 & 2.5 & 0.41 & 4.4 \\
ECAP-S25-T200 & 42 & 2.7 & 0.41 & 4.8 \\
ECAP-S50-T200 & 39 & 2.6 & 0.41 & 4.2 \\
ECAP-S25-T160 & 40 & 2.7 & 0.41 & 4.3 \\
ECAP-S25-T180 & 38 & 2.7 & 0.41 & 4.3 \\
ECAP-S25-T190 & 35 & 2.6 & 0.41 & 4.2 \\
ECAP-S25-T210 & 35 & 2.7 & 0.41 & 4.3 \\
\hline
\end{tabular}

Figure 6 shows the Fourier Transform Infrared Spectroscopy (FTIR) absorbance spectra for HW, HP-T200, and ECAP-S25-T200. The lateral order index (LOI) [14], which is related to the crystallinity of cellulose, is defined by the ratio between the heights of the absorbance bands at $1420-1430 \mathrm{~cm}^{-1}$ (symmetric $\mathrm{CH}_{2}$ bending, indicative of crystalline structure) and $893-898 \mathrm{~cm}^{-1}$ (asymmetric out of phase glucose ring stretching) [14]. The hydrogen bond intensity (HBI), defined as the band height ratio between $\sim 3400 \mathrm{~cm}^{-1}$ (O-H stretching, $\mathrm{H}$-bonds between molecules) and $\sim 1320 \mathrm{~cm}^{-1}(\mathrm{CH}$ rocking vibration of the glucose ring or crystalline cellulose $\mathrm{CH}_{2}$ ), is also determined to show the intermolecular interactions, crystallinity, and amount of water [15]. Cross-linked lignin ratio (CLL) obtained from the ratio between band heights at $1504 \mathrm{~cm}^{-1}$ and $1590 \mathrm{~cm}^{-1}$ (aromatic structures skeletal vibration) could be used to evaluate the proportion of condensed and crosslinked G-type lignin, with a higher CLL indicating a higher percentage of condensed and crosslinked structures in lignin $[16,17]$. In addition, $\mathrm{I}_{1735} / \mathrm{I}_{1650}$ is used to indicate non-conjugated $>\mathrm{C}=\mathrm{O}\left(1735 \mathrm{~cm}^{-1}\right)$ relative to conjugated groups $\left(1650 \mathrm{~cm}^{-1}\right)$. These ratios are listed in Table 2 . 


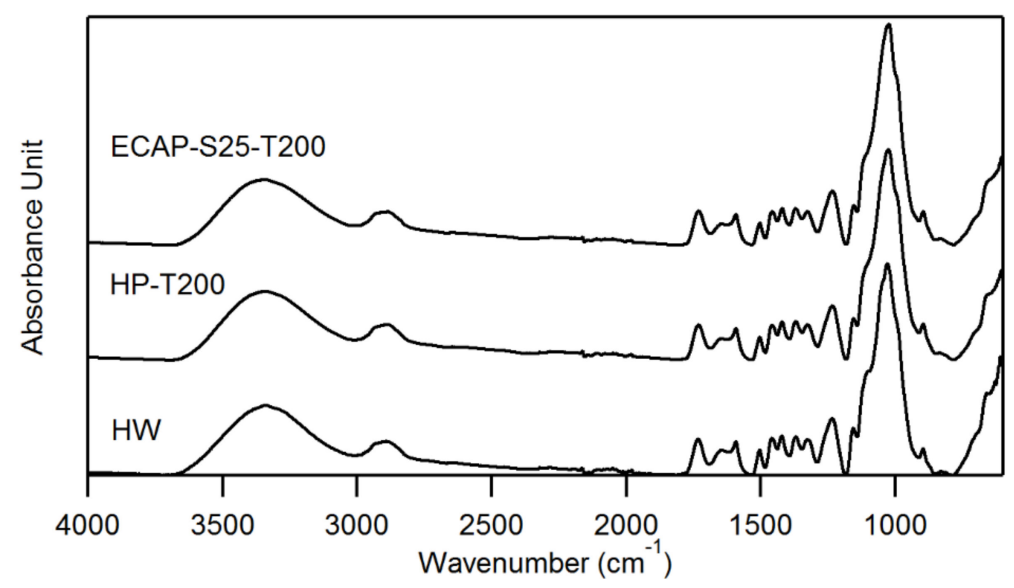

Figure 6. Fourier Transform Infrared Spectroscopy (FTIR) spectra from 4000 to $600 \mathrm{~cm}^{-1}$ for HW, HP-T200, and ECAP-S25-T200.

Table 2. FTIR peak ratios of HW under various conditions.

\begin{tabular}{ccccc}
\hline Material & $\begin{array}{c}\mathbf{I}_{\mathbf{1 4 2 2}} / \mathbf{I}_{\mathbf{8 9 5}} \text { Lateral } \\
\text { Order Index (LOI) }\end{array}$ & $\begin{array}{c}\mathbf{I}_{\mathbf{1 5 0 4}} / \mathbf{I}_{\mathbf{1 5 9 0}} \\
\text { Cross-Linked } \\
\text { Lignin Ratio (CLL) }\end{array}$ & $\begin{array}{c}\mathbf{I}_{\mathbf{3 4 0 0}} / \mathbf{I}_{\mathbf{1 3 2 8}} \\
\text { Hydrogen Bond } \\
\text { Intensity (HBI) }\end{array}$ & $\mathbf{I}_{\mathbf{1 7 3 5}} / \mathbf{I}_{\mathbf{1 6 5 0}}$ \\
\hline HW & 1.2 & 0.68 & 2.8 & 1.8 \\
HP-T200 & 1.0 & 0.67 & 3.1 & 2.2 \\
ECAP-S10-T200 & 0.95 & 0.68 & 3.0 & 2.1 \\
ECAP-S25-T200 & 0.99 & 0.68 & 3.1 & 2.2 \\
ECAP-S50-T200 & 0.98 & 0.66 & 3.2 & 2.0 \\
ECAP-S25-T160 & 0.96 & 0.65 & 3.0 & 1.9 \\
ECAP-S25-T180 & 0.94 & 0.65 & 3.1 & 1.9 \\
ECAP-S25-T190 & 0.99 & 0.67 & 3.1 & 2.1 \\
ECAP-S25-T210 & 0.95 & 0.69 & 3.2 & 2.1 \\
\hline
\end{tabular}

In comparison with HW before processing, HP and ECAP caused decreases in LOI, indicating degradation of crystalline cellulose. The increase in HBI suggests the degradation of amorphous cellulose, less absorbed water due to heat treatment [18], or an increase in hydrogen bonds between cellulose chains thanks to deformation. The samples after ECAP generally possess lower LOI than HP-T200, indicating more disorder in cellulose caused by shear deformation.

The $\mathrm{I}_{1735} / \mathrm{I}_{1650}$ ratio increases after both HP and ECAP. For ECAP consolidated samples, $\mathrm{I}_{1735} / \mathrm{I}_{1650}$ shows an increase with temperature up to $190^{\circ} \mathrm{C}$, while CLL also increases as temperature rises from 160 to $210^{\circ} \mathrm{C}$. With an increase in ECAP temperature, lignin becomes more condensed due to the loss of methoxyl groups, $\mathrm{S}$ units, or cleavage of aliphatic parts, and consequently there is more non-conjugated $>C=O$ relative to conjugated groups, increasing the $\mathrm{I}_{1735} / \mathrm{I}_{1650}$ peak ratio $[19,20]$. Hemicellulose degradation also occurs at high temperatures [21-23].

Figure 7 compares the TGA and DTG curves for HW, HP-T200, and ECAP-S25-T200. All the samples had $4-6 \%$ water loss at low temperatures. The major DTG peak occurred at $\sim 360{ }^{\circ} \mathrm{C}$, which signals the HW degradation with the order of degradation temperature as HW > HP-T200 $>$ ECAP-S25-T200. In fact, all ECAP processed samples showed similar thermal stability with DTG peak temperatures at $355-358{ }^{\circ} \mathrm{C}$. The decrease in the major DTG peak temperature can be ascribed to disrupted crystalline domains and decreases in crystallinity after ECAP processing, as the decomposition temperature of cellulose is related to crystallite size and crystallinity [12,24]. Also, the major DTG peaks in Figure $7 \mathrm{~b}$ display shoulders from hemicellulose [12] at $250-300{ }^{\circ} \mathrm{C}$. This temperature range for hemicellulose degradation seems to decrease in the same order of $\mathrm{HW}>$ HP-T200 > ECAP-S25-T200, corresponding to the shift of the DTG peaks. 
(a)

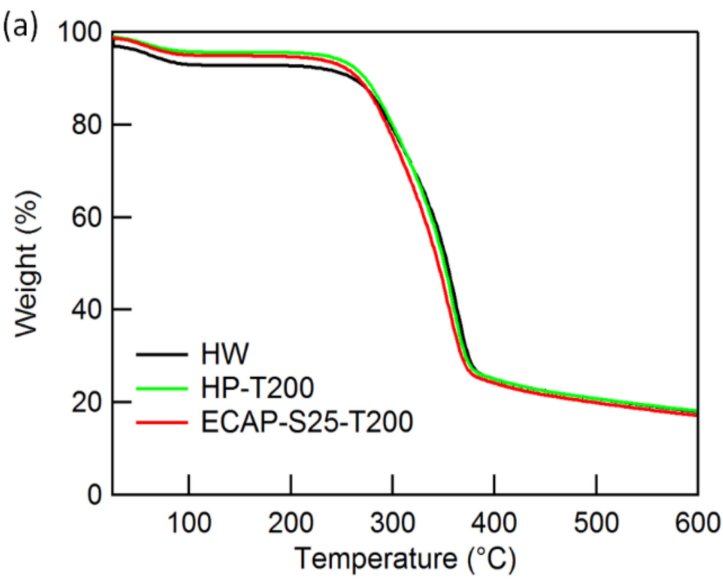

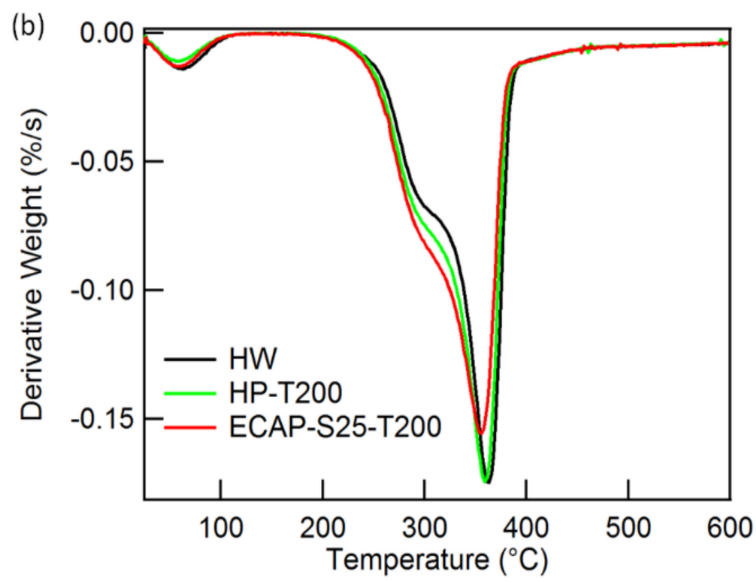

Figure 7. Comparison between HW, HP-T200, and ECAP-S25-T200: (a) TGA and (b) DTG.

\section{Discussion}

It is obvious that ECAP has facilitated the bonding of particles, as there are few cracks between individual particles that tend to be common in the hot-pressed material, despite the periodic cracks across the entire cross section under certain conditions. According to a previous study [25], shear during compaction of cellulose particles can enhance their consolidation. It appears that shear deformation during ECAP has similar effects in terms of enhancing sliding of particles against each other, increasing the contact area, and reducing the gaps. However, as HW particles are inherently brittle, severe shear deformation would cause parallel cracks along the shear plane at $\sim 45^{\circ}$ relative to the pressing direction with regular spacing (Figures 1-3). Under some conditions, shear bands would form, leading to large regions of distorted cells (Figure 4).

The periodic localized deformation causing shear bands or cracks has been found in ECAP of both polymers and metals [26-28]. This unstable flow during ECAP occurs in metals with a low strain hardening rate when adiabatic heating is prevalent, causing "flow softening" and localized shear [26]. The inhomogeneous deformation during ECAP of polypropylene $[27,28]$ is related to the "stick-slip" phenomenon, with plastic deformation only at the surface during stiction, resulting in less-deformed regions.

The HW particles in the less deformed region between the periodic cracks or between the shear bands tend to lie horizontal, i.e., largely aligned with the pressing direction (Figures 2-4), with limited deformation of cell walls other than collapse (Figure $5 b, c$ ). On the other hand, the particles next to a shear band or a periodic crack tend to orient at a higher angle. These observations conform to the modeling of the unstable flow softening materials during ECAP, which showed grids at a low angle at the less-deformed region and at $\sim 45^{\circ}$ in the shear concentrated region [29].

Cell structures are recognizable in these less-deformed regions, while more severe deformation inside a shear band or next to periodic cracks appears to have completely distorted the cells, giving rise to local good inter-particle bonding with little cracking. Compared to samples with periodic cracks only, samples with broad shear bands experienced a more homogenous deformation, with reduction in brittle cracking (Figure 5f). In other words, it is potentially possible to create highly dense and well-bonded HW without any additive, as shown in Figure $5 f$, if a method can be found to avoid the formation of the periodic cracks. Research on this is currently in progress, with encouraging results.

It is noted that no such shear bands were found in the ECAP consolidated HW with addition of PEI [9], although similar features, such as periodic cracking, collapsed cells in the less deformed region, and severely distorted cells next to the cracks, were observed in both. This is because PEI acted as a plasticizer and facilitated the sliding and rotation of HW particles upon severe shearing. Instead, the bonding in PEI-containing HW is enhanced by cross linking between HW particles and PEI [9], which is not present in the additive-free HW here (Figure 6). The lack of particle sliding and rotation also resulted in nearly horizontally oriented wood cells (Figure 3), compared to the much higher angles in 
the PEI-containing material (Figure 2 in [9]). In addition, PEI reduced thermal stability, with the major DTG peak shifting from $\sim 356{ }^{\circ} \mathrm{C}$ (Figure $7 \mathrm{~b}$ ) to $\sim 330{ }^{\circ} \mathrm{C}[9]$.

Both HP and ECAP involve heating to elevated temperatures for various durations of time. Above a certain critical temperature, a short time could cause an increase in cellulose crystallinity [30], whereas a long time could lead to a decrease $[18,30]$. On the other hand, crystallinity may also increase at low pressure or decrease at high pressure when processed by hot pressing, as in the cases of corn stalk at $\sim 5 \mathrm{MPa}$ [31] and cellulose at $>100 \mathrm{MPa}$ [25], respectively. ECAP of HW leads to lower crystallinity and smaller crystallite size compared to HP (Table 1), and this is also confirmed by the FTIR (LOI in Table 2) and TGA results and is consistent with previous findings $[6,7,25,32,33]$.

Both ECAP pressing speed and temperature affect crack formation in HW. At lower temperatures, e.g., $160-180{ }^{\circ} \mathrm{C}$, cracking occurred due to the rigid chain structure, which could not sustain the plastic deformation. At a higher temperature, e.g., $190^{\circ} \mathrm{C}$, deformation in $\mathrm{HW}$ caused the degradation of hemicellulose and lignin condensation (shown by the increase in $\mathrm{I}_{1735} / \mathrm{I}_{1650}$ ), leaving pores and delamination [23]. At $200{ }^{\circ} \mathrm{C}$, it seems most of the wood components achieved some mobility by thermal softening [34], generating additional chain movement or reorientation for sliding between wood cells or even cellulose fibrils, consequently reducing fracture [35]. Consequently, the plastic deformation was promoted among different components of HW, although periodic cracks still existed. This is proven by the formation of shear bands or homogeneous shear deformation at a higher temperature of $210{ }^{\circ} \mathrm{C}(25 \mathrm{~mm} / \mathrm{min})$ or at a lower speed of $10 \mathrm{~mm} / \mathrm{min}\left(200^{\circ} \mathrm{C}\right)$, implying further enhanced mobility. Slow speeds and high temperatures are indeed suggested for eliminating unsteady flow and cracks in ECAP of titanium [36]. Although the unstable flow did not cause cracking in ECAP of polypropylene, a lower speed allowed more homogeneous deformation at room temperature [27]. It should be noted, however, that temperatures higher than $210{ }^{\circ} \mathrm{C}$ would accelerate thermal decomposition of wood particles and should be avoided.

\section{Summary and Conclusions}

ECAP consolidation of HW without any additives was conducted to study the effects of processing parameters, such as temperature and pressing speed, on cracking, wood cell deformation, crystallinity, bonding, and thermal stability of the resulting biocomposites. Although large periodic cracks were present due to shear localisation and lack of ductility in HW, severe deformation of the wood cells was observed inside shear bands between periodic cracks and in some areas next to the periodic cracks. The wood particles were well bonded without cracking in these regions, indicating the positive effects of severe shearing on consolidation. The other consequences of severe shearing included reduced crystallinity and crystallite size. The mobility of chains was found to increase with decreasing speed and increasing temperature. Although work on eliminating the detrimental periodic cracks is still in progress, the present study points to potential achievement of cracking-free HW consolidated without binder and with good strength.

Author Contributions: Conceptualization, X.Z. and K.X.; formal analysis, Y.B.; investigation, Y.B.; methodology, Y.B. and K.X.; resources, K.X.; supervision, X.Z. and K.X.; writing-original draft, Y.B.; writing-review and editing, X.Z. and K.X.

Funding: This research received no external funding.

Acknowledgments: We would like to thank Roger Curtain from the Bio 21 Advanced Microscopy Facility (the University of Melbourne), Liz Goodall from Materials Characterisation and Fabrication Platform (the University of Melbourne), Weidong Yang from CSIRO, and Edward Lui from RMIT University for their valuable assistance with experiments. Yu Bai acknowledges financial support from the Research Training Program (RTP) Scholarship and Melbourne Research Scholarship (MRS).

Conflicts of Interest: The authors declare no conflict of interest. 


\section{References}

1. Valiev, R.Z.; Langdon, T.G. Principles of equal-channel angular pressing as a processing tool for grain refinement. Prog. Mater. Sci. 2006, 51, 881-981. [CrossRef]

2. Xia, K. Consolidation of particles by severe plastic deformation: Mechanism and applications in processing bulk ultrafine and nanostructured alloys and composites. Adv. Eng. Mater. 2010, 12, 724-729. [CrossRef]

3. Sue, H.-J.; Li, C.K.-Y. Control of orientation of lamellar structure in linear low density polyethylene via a novel equal channel angular extrusion process. J. Mater. Sci. Lett. 1998, 17, 853-856. [CrossRef]

4. Xia, Z.; Sue, H.-J.; Hsieh, A.J.; Huang, J.W.-L. Dynamic mechanical behavior of oriented semicrystalline polyethylene terephthalate. J. Polym. Sci. Part B Polym. Phys. 2001, 39, 1394-1403. [CrossRef]

5. Beloshenko, V.A.; Voznyak, Y.V.; Reshidova, I.Y.; Naï-Abdelaziz, M.; Zairi, F. Equal-channel angular extrusion of polymers. J. Polym. Res. 2013, 20. [CrossRef]

6. Zhang, X.; Wu, X.; Gao, D.; Xia, K. Bulk cellulose plastic materials from processing cellulose powder using back pressure-equal channel angular pressing. Carbohydr. Polym. 2012, 87, 2470-2476. [CrossRef]

7. Zhang, X.; Wu, X.; Haryono, H.; Xia, K. Natural polymer biocomposites produced from processing raw wood flour by severe shear deformation. Carbohydr. Polym. 2014, 113, 46-52. [CrossRef] [PubMed]

8. Zhang, X.; Wu, X.; Xia, K. Cellulose-wheat gluten bulk plastic materials produced from processing raw powders by severe shear deformation. Carbohydr. Polym. 2013, 92, 2206-2211. [CrossRef]

9. Bai, Y.; Zhang, X.; Xia, K. High strength biocomposites consolidated from hardwood particles by severe plastic deformation. Cellulose 2019, 26, 1067-1084. [CrossRef]

10. Zhang, X.; Gao, D.; Wu, X.; Xia, K. Bulk plastic materials obtained from processing raw powders of renewable natural polymers via back pressure equal channel angular consolidation (BP-ECAC). Eur. Polym. J. 2008, 44, 780-792. [CrossRef]

11. Park, S.; Baker, J.O.; Himmel, M.E.; Parilla, P.A.; Johnson, D.K. Cellulose crystallinity index: Measurement techniques and their impact on interpreting cellulase performance. Biotechnol. Biofuels 2010, 3, 10-19. [CrossRef]

12. Poletto, M.; Zattera, A.J.; Forte, M.M.C.; Santana, R.M.C. Thermal decomposition of wood: Influence of wood components and cellulose crystallite size. Bioresour. Technol. 2012, 109, 148-153. [CrossRef]

13. Driemeier, C.; Pimenta, M.T.B.; Rocha, G.J.M.; Oliveira, M.M.; Mello, D.B.; Maziero, P.; Gonçalves, A.R. Evolution of cellulose crystals during prehydrolysis and soda delignification of sugarcane lignocellulose. Cellulose 2011, 18, 1509-1519. [CrossRef]

14. O'Connor, R.T.; DuPré, E.F.; Mitcham, D. Applications of infrared absorption spectroscopy to investigations of cotton and modified cottons:Part I: Physical and crystalline modifications and oxidation. Text. Res. J. 1958, 28, 382-392. [CrossRef]

15. Oh, S.Y.; Yoo, D.I.; Shin, Y.; Seo, G. FTIR analysis of cellulose treated with sodium hydroxide and carbon dioxide. Carbohydr. Res. 2005, 340, 417-428. [CrossRef] [PubMed]

16. Auxenfans, T.; Crônier, D.; Chabbert, B.; Paës, G. Understanding the structural and chemical changes of plant biomass following steam explosion pretreatment. Biotechnol. Biofuels 2017, 10, 36. [CrossRef] [PubMed]

17. Mann, D.G.J.; Labbé, N.; Sykes, R.W.; Gracom, K.; Kline, L.; Swamidoss, I.M.; Burris, J.N.; Davis, M.; Stewart, C.N. Rapid assessment of lignin content and structure in switchgrass (Panicum virgatum L.) grown under different environmental conditions. BioEnergy Res. 2009, 2, 246-256. [CrossRef]

18. Yuan, J.-M.; Feng, Y.-R.; He, L.-P. Effect of thermal treatment on properties of ramie fibers. Polym. Degrad. Stab. 2016, 133, 303-311. [CrossRef]

19. Esteves, B.; Velez Marques, A.; Domingos, I.; Pereira, H. Chemical changes of heat treated pine and eucalypt wood monitored by FTIR. Maderas Cienc. Tecnol. 2013, 15, 245-258. [CrossRef]

20. González-Peña, M.M.; Curling, S.F.; Hale, M.D.C. On the effect of heat on the chemical composition and dimensions of thermally-modified wood. Polym. Degrad. Stab. 2009, 94, 2184-2193. [CrossRef]

21. Esteves, B.M.; Pereira, H.M. Wood modification by heat treatment: A review. BioResources 2009, 4, 370-404.

22. Nuopponen, M.; Vuorinen, T.; Jämsä, S.; Viitaniemi, P. Thermal modifications in softwood studied by FT-IT and UV resonance Raman spectroscopies. J. Wood Chem. Technol. 2005, 24, 13-26. [CrossRef]

23. Ling, Z.; Ji, Z.; Ding, D.; Cao, J.; Xu, F. Microstructural and topochemical characterization of thermally modified poplar (Populus cathayaha) cell wall. BioResources 2016, 11, 786-799. [CrossRef] 
24. Kim, U.-J.; Eom, S.H.; Wada, M. Thermal decomposition of native cellulose: Influence on crystallite size. Polym. Degrad. Stab. 2010, 95, 778-781. [CrossRef]

25. Ek, R.; Wormald, P.; östelius, J.; Iversen, T.; Nyström, C. Crystallinity index of microcrystalline cellulose particles compressed into tablets. Int. J. Pharm. 1995, 125, 257-264. [CrossRef]

26. Segal, V.M. Equal channel angular extrusion: From macromechanics to structure formation. Mater. Sci. Eng. A 1999, 271, 322-333. [CrossRef]

27. Boulahia, R.; Gloaguen, J.M.; Zaïri, F.; Naït-Abdelaziz, M.; Seguela, R.; Boukharouba, T.; Lefebvre, J.M. Deformation behaviour and mechanical properties of polypropylene processed by equal channel angular extrusion: Effects of back-pressure and extrusion velocity. Polymer 2009, 50, 5508-5517. [CrossRef]

28. Qiu, J.; Murata, T.; Wu, X.; Kitagawa, M.; Kudo, M. Plastic deformation mechanism of crystalline polymer materials in the equal channel angular extrusion process. J. Mater. Process. Technol. 2012, 212, 1528-1536. [CrossRef]

29. Figueiredo, R.B.; Cetlin, P.R.; Langdon, T.G. Stable and unstable flow in materials processed by equal-channel angular pressing with an emphasis on magnesium alloys. Metall. Mater. Trans. A 2010, 41,778-786. [CrossRef]

30. Bhuiyan, M.T.R.; Hirai, N.; Sobue, N. Changes of crystallinity in wood cellulose by heat treatment under dried and moist conditions. J. Wood Sci. 2000, 46, 431-436. [CrossRef]

31. Le, X.; An, J.; Zhang, G.; Wang, L.; Fan, J.; Wang, P.; Xie, Y. Investigation of the structural characteristics of corn stalk during hot-pressing. BioResources 2016, 11, 10213-10225. [CrossRef]

32. Ji, Z.; Ma, J.-F.; Zhang, Z.-H.; Xu, F.; Sun, R.-C. Distribution of lignin and cellulose in compression wood tracheids of Pinus yunnanensis determined by fluorescence microscopy and confocal Raman microscopy. Ind. Crops Prod. 2013, 47, 212-217. [CrossRef]

33. Gravitis, J.; Kokorevics, A.; Zharov, A.; Lippmaa, E. Structural changes of wood and its components initiated by the simultaneous action of shear deformation and high pressure. J. Pulp Pap. Sci. 1991, 17, J119-J123.

34. Laborie, M.P.G. The Temperature Dependence of Wood Relaxations: A Molecular Probe of the Woody Cell Wall. In Characterization of the Cellulosic Cell Wall, 1st ed.; Stokke, D.D., Groom, L.H., Eds.; Blackwell Publishing: Ames, IA, USA, 2008; pp. 87-94.

35. Keckes, J.; Burgert, I.; Frühmann, K.; Müller, M.; Kölln, K.; Hamilton, M.; Burghammer, M.; Roth, S.V.; Stanzl-Tschegg, S.; Fratzl, P. Cell-wall recovery after irreversible deformation of wood. Nat. Mater. 2003, 2, 810-813. [CrossRef] [PubMed]

36. Semiatin, S.L.; DeLo, D.P.; Segal, V.M.; Goforth, R.E.; Frey, N.D. Workability of commercial-purity titanium and 4340 steel during equal channel angular extrusion at cold-working temperatures. Metall. Mater. Trans. A 1999, 30, 1425-1435. [CrossRef]

(C) 2019 by the authors. Licensee MDPI, Basel, Switzerland. This article is an open access article distributed under the terms and conditions of the Creative Commons Attribution (CC BY) license (http://creativecommons.org/licenses/by/4.0/). 